\title{
ANALISIS EFEKTIVITAS DAN KONTRIBUSI PAJAK MINERAL BUKAN LOGAM DAN BATUAN TERHADAP PENDAPATAN ASLI DAERAH DI KABUPATEN MINAHASA
}

\author{
Billy Ch. G. Rattu \\ Agus T. Poputra \\ Meily Y. B. Kalalo \\ Fakultas Ekonomi dan Bisnis, Jurusan Akuntansi \\ Universitas Sam Ratulangi Manado \\ Email: billrattu09@gmail.com
}

\begin{abstract}
Own-Source Revenue is a source of regional financial and funding of the government. One of the revenues comes from local tax, and that becomes one of the government of MinahasaRegency is Non Metallic Minerals Tax and Rocks. This research was conducted to determine the level of effectiveness and contributions Non Metallic Minerals Tax and Rocks as a source of revenue Minahasa regency.Non Metallic Minerals Tax and Rocks is tax on the extraction of non metallic minerals and rocks, either from natural sources inside and/or the surface of the earth to be used. The method of research is using qualitative descriptive data types. The research is confined to the calculation of the percentage of effectiveness and contributions obtained from the quantitative data relating to the acceptance of Non Metallic Minerals Tax and Rocks. The results of research suggests that the effectiveness of Non Metallic Minerals Tax and Rocks in 2012, 2013 and 2014 year is "very effective" and effectiveness rate is highest in 2014 which amounted to $159.20 \%$.Meanwhile, the contribution rate of Non Metallic Minerals Tax and Rocks in the last three years continues to decline so that the criteria included the contribution is "very less". Tax collection system should be kept under surveillance so that tax revenue of Metallic Minerals Tax and Rocks controlled and remains highly effective .
\end{abstract}

Keywords: revenue, non metallic minerals tax and rocks, effectiveness, contributions

\section{Latar Belakang}

\section{PENDAHULUAN}

Pada tanggal 1 Januari 2001 di Indonesia secara resmi diberlakukan otonomi daerah, yang berarti daerah diberikan hak, kewenangan dan kewajiban untuk mengatur dan mengurus sendiri urusan pemerintahan dan masyarakat setempat dalam sistem Negara Kesatuan Republik Indonesia. Penyelenggaraan otonomi daerah yang luas, nyata dan bertanggung jawab diperlukan kemampuan daerah untuk menggali sumber keuangan sendiri yang didukung oleh perimbangan keuangan antara Pemerintah Pusat dan Daerah (Ridha dan Dhiah, 2013). Pemerintah daerah tidak hanya dituntut untuk mampu menyelenggarakan pemerintahan, pembangunan dan pelayanan akan tetapi secara finansial mampu untuk membiayai kebutuhannya.

Salah satu tugas Pemerintah Daerah adalah memperhatikan penggunaan dan pengelolaan pendapatan daerah secara efektif. Pendapatan daerah antara lain Pendapatan Asli Daerah (PAD). Pendapatan Asli Daerah (PAD) inilah yang merupakan salah satu modal utama untuk mendukung proses pembangunan di daerah sehingga berkenan dengan kepentingan rakyat. Dengan demikian, penerimaan dan pengelolaan pendapatan daerah harus diperhatikan (Pingkan, 2015). Pendapatan Asli Daerah (PAD) berasal dari Pajak Daerah dan Retribusi Daerah. Pajak daerah di Indonesia berdasarkan Undang-undang nomor 28 tahun 2009 terbagi menjadi dua yaitu, pajak provinsi dan pajak kabupaten/kota. Pembagian ini dilakukan sesuai dengan kewenangan pengenaan dan pemungutan masing-masing jenis pajak daerah pada wilayah administrasi provinsi atau kabupaten/kota.

Pajak merupakan peralihan kekayaan dari pihak rakyat kepada kas negara untuk mebiayai pengeluaran rutin dan surplusnya digunakan untuk public saving yang merupakan sumber utama untuk membiayai public investment (Resmi, 2011:1). Salah satu penerimaan Pendapatan Asli Daerah berasal dari sektor pajak daerah. Salah satu bentuk penataan kembali retribusi yang pada hakikatnya bersifat pajak yaitu Pajak Mineral Bukan Logam dan Batuan. Pajak Mineral Bukan Logam dan 
Batuan adalah pajak atas kegiatan pengambilan mineral bukan logam dan batuan, baik dari sumber alam di dalam dan/atau permukaan bumi untuk dimanfaatkan (Samudra, 2015:246).

Di Kabupaten Minahasa terdapat berbagai macam usaha entah usaha orang pribadi dan/atau badan yang dapat sangat mempengaruhi Pendapatan Asli Daerah. Maka, Komponen pajak daerah yang perlu mendapatkan perhatian lebih oleh pemerintah Kabupaten Minahasa adalah Pajak Mineral Bukan Logam dan Batuan seiring meningkatnya kebutuhan akan bahan mineral bukan logam dan batuan yang digunakan sebagai bahan dasar industri dan pembangunan pemukiman di daerah kabupaten Minahasa sendiri dan sekitarnya.

\section{Tujuan Penelitian}

Tujuan penelitian ini adalah untuk mengetahui tingkat Efektivitas dan besarnya Kontribusi Pajak Mineral Bukan Logam Dan Batuan terhadap Pendapatan Asli Daerah di Kabupaten Minahasa.

\section{Akuntansi Pajak}

\section{TINJAUAN PUSTAKA}

Suwardjono (2014:5) Akuntansi adalah seni pencatatan, penggolongan, dan peringkasan transaksi dan kejadian yang bersifat keuangan dengan cara yang berdaya guna dan dalam bentuk satuan uang, dan penginterpretasian hasil proses tersebut. Hery (2014:1) mengemukakan Akuntansi Pajak adalah menyiapkan dan melaporkan perhitungan pajak terutang serta melakukan perencanaan pajak. Akuntansi pajak juga merupakan akuntansi yang berkaitan dengan perhitungan perpajakan dan mengacu pada peraturan dan perundang-undangan perpajakan beserta aturan pelaksanaannya (Londorang, 2014).

\section{Konsep Perpajakan}

Edwin R. A. Seligmanyang dikutip dalam Waluyo (2013:2)mendefinisikan bahwapajak adalah adanya kontribusi seseorang yang ditujukan kepada negara tanpa adanya manfaat yang ditujukan secara khusus pada seseorang. Memang demikian halnya bahwa bagaimanapun juga pajak itu ditujukan manfaatnya kepada masyarakat.

\section{Fungsi Pajak}

Pajak terdiri atas 2 (dua) fungsi sebagai berikut (Waluyo 2013:6).

1. Fungsi Budgetir yaitu pajak sebagai sumber dana yang diperuntukkan bagi pembiayaan pengeluaran-pengeluaran pemerintah.

2. Fungsi Mengatur yaitu pajak sebagai alat untuk mengatur atau melaksanakan kebijakan di bidang sosial dan ekonomi.

\section{Pendapatan Asli Daerah (PAD)}

Pendapatan asli daerah adalah semua hak daerah yang diakui sebagai penambah nilai kekayaan bersih dalam periode anggaran tertentu (Undang-undang No. 32 tahun 2004 tentang pemerintahan daerah). Pendapatan Asli Daerah dalam Undang-undang no. 28 tahun 2009 merupakan sumber keuangan daerah yang digali dari wilayah daerah yang bersangkutan yang terdiri dari hasil pajak daerah, hasil retribusi daerah, hasil pengelolaan kekayaan daerah yang dipisahkan dan lain-lain yang merupakan pendapatan asli daerah yang sah.

\section{Pajak Daerah}

Pajak Daerah yang selanjutnya disebut pajak, adalah kontribusi wajib kepada daerah yang terutang oleh orang pribadi atau badan yang bersifat memaksa berdasarkan Undang-undang, dengan tidak mendapatkan imbalan secara langsungdan digunakan untuk keperluan daerah bagi sebesarbesarnya kemakmuran rakyat (Mardiasmo 2011:12).

\section{Jenis-jenis Pajak Daerah}

Pajak daerah dibagai menjadi 2 (dua) bagian sebagai berikut (Mardiasmo 2011:13).

1. Pajak Provinsi, terdiri dari 5 (lima) pajak sebagai berikut.
a. pajak kendaraan bermotor;
b. pajak bea balik nama kendaraan bermotor;
c. pajak bahan bakar kendaraan bermotor;
d. pajak air permukaan; dan
e. pajak rokok.

2. Pajak Kabupaten/Kota, terdiri dari 11 (sebelas) pajak sebagai berikut. a. pajak hotel; 


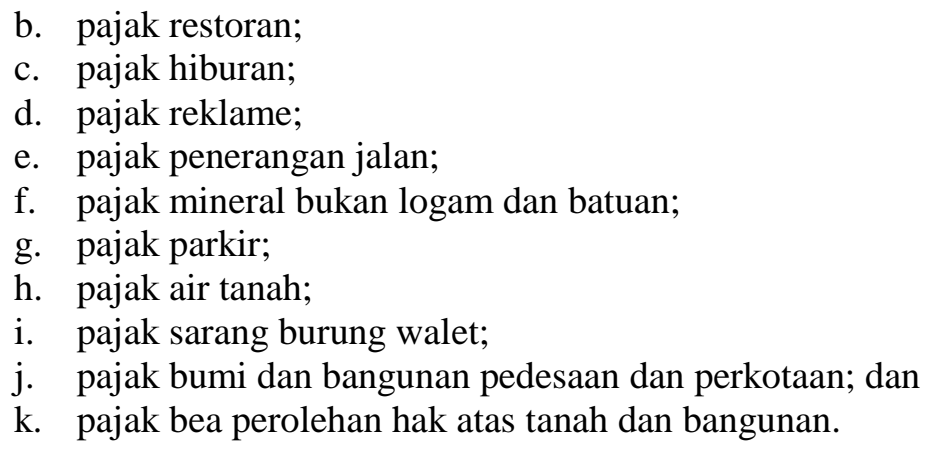

\section{Pajak Mineral Bukan Logam Dan Batuan}

Undang-Undang No. 28 tahun 2009 Pasal 1 menyatakan bahwa Pajak Mineral Bukan Logam Dan Batuan adalah pajak atas kegiatan pengambilan mineral bukan logam dan batuan, baik dari sumber alam di dalam dan/atau permukaan bumi untuk dimanfaatkan. Pajak Mineral Bukan Logam dan Batuan adalah pajak atas kegiatan pengambilan bahan mineral bukan logam dan batuan sesuai dengan peraturan perundang-undangan yang berlaku (Samudra 2015:247).

\section{Penelitian Terdahulu}

Pamela Indira Lasut (2014) melakukan penelitian dengan judul Efektivitas Penerimaan Pajak dan Pengolahan Mineral Bukan Logam Dan Batuan sebagai Sumber Pendapatan Asli Daerah Kota Tomohon. Tujuan penelitian ini untuk menghitung efektivitas dan kontribusi Pajak Mineral Bukan Logam dan Batuan sebagai Sumber Pendapatan Asli Daerah Kota Tomohon. Hasil dari penelitian ini Perhitungan efektivitas dan kontribusi pada tahun 2009 sampai pada tahun 2013 disimpulkan tingkat efektivitas pajak pada tahun tersebut tidak efektif dan kontribusi pajak pada tahun itu juga sangat kurang.

Indah Rahmawati (2014) melakukan penelitian dengan judul Analisis Potensi Penerimaan Pajak Mineral Bukan Logam Dan Batuan Sebagai Sumber Pendapatan Asli Daerah Di Kabupaten Gresik. Tujuan dari penelitian ini untuk menghitung potensi pajak mineral bukan logam di Kabupaten Gresik. Hasil dari penelitian ini,Potensi Pajak Mineral Bukan Logam Dan Batuan terus mengalami kenaikan di tiap tahunnya.

\section{Jenis Penelitian}

\section{METODE PENELITIAN}

Dalam penelitian ini penulis menggunakan jenis data penelitian deskriptif kualitatif. Penelitian hanya terbatas pada perhitungan besarnya prosentase efektivitas dan kontribusi yang didapat dari data kuantitatif yang berkaitan dengan penerimaan Pajak Mineral Bukan Logam dan Batuan yakni menjelaskan atau menguraikan hasil Laporan Realisasi Anggaran Pajak Daerah Kabupaten Minahasa tahun 2012-2014 dan Laporan Realsisasi Anggaran Pendapatan Asli Daerah (PAD) Kabupaten Minahasa dari tahun 2012-2014.

\section{Tempat dan Waktu Penelitian}

Penelitian ini bertempat di Badan Pengelola Keuangan dan Barang Milik Daerah Kabupaten Minahasa dan Dinas Energi dan Sumber Daya Mineral. Waktu yang ditempuh untuk penelitian ini adalah selama 2 (dua) bulan yang meliputi kegiatan pengumpulan data.

\section{Teknik Pengumpulan Data}

Untuk memperoleh informasi dan data yang dikelolah dalam penelitian ini, maka pengumpulan data dilakukan dengan dua cara sebagai berikut.

1. Penelitian Kepustakaan (library research).

2. Penelitian Lapangan (field research).

Adapun hal-hal yang dilakukan sebagai berikut.

a. Wawancara (Interview).

Pengumpulan data ini dilakukan dengan melakukan tanya jawab baik pimpinan maupun karyawan yang berada di Badan Pengolahan Keuangan dan Barang Milik Daerah Kabupaten Minahsasa dan Dinas Energi dan Sumber Daya Mineral Kabupaten Minahasa guna memperoleh informasi yang lebih jelas mengenai masalah yang dibahas dalam penelitian ini. 


\section{Metode Analisis}

b. Dokumentasi (Documentation).

Pengumpulan dokumen dalam penelitian ini berupa data yang diperoleh baik dari perpustakaan maupun laporan realisasi pendapatan asli daerah Kabupaten Minahasa.

Metode yang digunakan adalah metode analisis deskriptif kualitatif. Analisis deskriptif kualitatif merupakan analisis yang diwujudkan dengan cara menggambarkan kenyataan atau keadaankeadaan atas suatu objek dalam bentuk uraian kalimat berdasarkan keterangan-keterangan dari pihakpihak yang berhubungan langsung dengan penelitian ini. Penelitian deskriptif kualitatif ini bertujuan untuk menjelaskan secara terperinci efektivitas dan kontribusi Pajak Mineral Bukan Logam dan Batuan terhadap pendapatan asli daerah di Kabupaten Minahasa.

\section{Definisi dan Pengukuran Operasaional Variabel}

Efektivitas

Efektivitas dalam hal ini mengetahui kondisi atau keadaan yang hendak dicapai telah memberikan hasil yang memuaskan, seperti yang dikemukakan Susilo yang dikutip dalam Adisasmita (2011). Namun efektivitas pajak adalah sesuatu yang dilihat dari hasil pajak yang telah terealisasi apakah sangat mempengaruhi hasil pendapatan dari target yang telah ditentukan.Dalam Rondonuwu (2015), besarnya peningkatan efektivitas Pajak Mineral Bukan Logam Dan Batuan dapat dihitung dengan rumus sebagai berikut.

\section{Realisasi Penerimaan Pajak Mineral Bukan Logam dan Batuan}

\section{Efektivitas $=-x 100 \%$ \\ Target Penerimaan Pajak Mineral Bukan Logam dan Batuan}

Adapun kriteria efektivitas dapat dilihat pada Tabel 1. sebagai berikut.

Tabel 1. Tabel Interpretasi Nilai Efektivitas

\begin{tabular}{cc}
\hline Presentase & Kriteria \\
\hline$>100 \%$ & Sangat efektif \\
$90-100 \%$ & Efektif \\
$80-90 \%$ & Cukup efektif \\
$60-80 \%$ & Kurang efektif \\
$<60 \%$ & Tidak efektif \\
\hline
\end{tabular}

\section{Kontribusi}

Sumber: Depdagri, Kemendagri No. 690.900.327 (Halim dalam Ricart, 2013)

Menurut Guritno yang dikutip dalam Puspitasari (2014) kontribusi adalah sesuatu yang diberikan bersama-sama dengan pihak lain untuk tujuan biaya atau kerugian tertentu atau bersama. Analisis yang digunakan untuk mengetahui seberapa besar kontribusi Pajak Mineral Bukan Logam Dan Batuan terhadap total Pendapatan Asli Daerah yang presentasenya dihitung dari realisasi Pajak Mineral Bukan Logam Dan Batuan dibandingkan dengan total realisasi pendapatan asli daerah. Untuk lebih jelasnya dapat dilihat dalam rumus sebagai berikut (Devy, 2013).

$$
\text { Kontribusi }=\frac{\text { Realisasi Penerimaan Pajak Mineral Bukan Logam dan Batuan }}{\text { Realisasi Pendapatan Asli Daerah }} \times 100 \%
$$

Adapun kriteria kontribusi dapat dilihat pada Tabel 2. sebagai berikut. 
Tabel 2. Tabel Interpretasi Nilai Kontribusi.

\begin{tabular}{cc}
\hline Presentase & Kriteria \\
\hline $0,00-10 \%$ & Sangat kurang \\
$10-20 \%$ & Kurang \\
$20,10-30 \%$ & Sedang \\
$30,10-40 \%$ & Cukup Baik \\
$40,10-50 \%$ & Baik \\
Diatas 50\% & Sangat Baik \\
\hline ber: Depdagri, Kemendagri No. 690.900.327(Halim dalam Ricart, 2013).
\end{tabular}

\section{Hasil Penelitian}

\section{HASIL PENELITIAN DAN PEMBAHASAN}

Untuk mengetahui berapa besar keefektivitas dan kontribusi Pajak Mineral Bukan Logam Dan Batuan maka diperlukan data berupa data target dan realisasi Pajak Mineral Bukan Logam Dan Batuan dan data target dan realisasi pendapatan asli daerah. Dalam hal ini, penulis akan menghitung efektivitas dan kontribusi Pajak Mineral Bukan Logam Dan Batuan Kabupaten Minahasa dalam kurun waktu 3 (tiga) tahun terakhir yaitu tahun 2012, 2013 dan tahun 2014. Untuk lebih jelasnya dapat dilihat pada Tabel 3. dan Tabel 4. berikut ini.

Tabel 3. Laporan Target dan Realisasi

Pajak Mineral Bukan Logam dan Batuan di Kabupaten Minahasa

Tahun 2012 - 2014

\begin{tabular}{ccr}
\hline Tahun & Target $(\mathbf{R P})$ & \multicolumn{1}{l}{ Realisasi (Rp) } \\
\hline 2012 & 2.000 .000 .000 & 2.199 .387 .592 \\
2013 & 2.000 .000 .000 & 2.604 .424 .720 \\
2014 & 2.300 .000 .000 & 3.661 .508 .488 \\
\hline
\end{tabular}

Sumber : Dinas Energi dan Sumber Daya Mineral, 2016

Tabel 4. Laporan Target dan Realisasi

Pendapatan Asli Daerah (PAD) di Kabupaten Minahasa

Tahun 2012 - 2014

\begin{tabular}{crr}
\hline \multirow{2}{*}{ Tahun } & \multicolumn{1}{c}{ Target (RP) } & \multicolumn{1}{c}{ Realisasi (Rp) } \\
\hline 2012 & 27.007 .276 .500 & 22.477 .366 .444 \\
2013 & 31.256 .367 .000 & 31.964 .854 .060 \\
2014 & 61.922 .781 .924 & $58.778 .368 .154,61$ \\
\hline
\end{tabular}

Sumber : BPKBMD Kabupaten Minahasa, 2016

Berdasarkan Tabel 3. dapat dilihat bahwa penerimaan pajak pada tahun 2012 sebesar Rp 2.199.387.592 telah mencapai target sebesar Rp 2.000.000.000 yang ditetapkan, pada tahun 2013 penerimaan pajak sebesar Rp 2.604.424.720 juga telah mencapai target sebesar Rp 2.000.000.000 dan pada tahun 2014 penerimaan pajak sebesar Rp 3.661.508.488 dari target sebesar 2.300.000.000. Dari hasil tersebut dapat disimpulkan bahwa penerimaan Pajak Mineral Bukan Logam Dan Batuan di Kabupaten Minahasa dari tahun 2012 sampai tahun 2014 telah mencapai target yang ditetapkan pemerintah. Dari ketiga tahun tersebut, pencapaian tertinggi terjadi pada tahun 2014 sedangkan yang terendah terjadi pada tahun 2012. 
Pada Tabel 4. dapat dilihat bahwa Pendapatan Asli Daerah Kabupaten Minahasa tahun 2012 sebesar Rp. 22.477.366.444 tidak memenuhi target yang telah ditentukan yakni sebesar Rp. 27.007.276.500. Pada tahun 2013 realisasi PAD sebesar Rp 31.964.854.060 telah mencapai target yang telah ditetapkan sebesar Rp 31.256.367.000. Sedangkan pada tahun 2014 realisasi PAD kembali tidak memenuhi target dari realisasi sebesar Rp. 58.778.368.154,61 pada target sebesar Rp. 61.922.781.924. Maka dapat disimpulkan Pendapatan Asli Daerah (PAD) Kabupaten Minahasa dari tahun ke tahun hanya sekali mencapai target yakni pada tahun 2013, sedangkan pada tahun 2012 dan tahun 2014 tidak memenuhi target yang ditetapkan.

Berikut merupakan hasil interpretasi Efektivitas Pajak Mineral Bukan Logam Dan Batuan di Kabupaten Minahasa Tahun 2012 - 2014 yang dapat dilihat pada Tabel 5. sebagai berikut.

Table 5. Efektivitas Pajak Mineral Bukan Logan dan Batuan

Kabupaten Minahasa

Tahun $2012-2014$

\begin{tabular}{crrrr}
\hline Tahun & Target Pajak (Rp) & $\begin{array}{c}\text { Realisasi Pajak } \\
(\text { Rp) }\end{array}$ & Efektivitas & Interpretasi \\
\hline 2012 & $2 . .000 .000 .000$ & 2.199 .387 .592 & $109.97 \%$ & Sangat Efektif \\
2013 & 2.000 .000 .000 & 2.604 .424 .720 & $130.22 \%$ & Sangat Efektif \\
2014 & 2.300 .000 .000 & 3.661 .508 .488 & $159.20 \%$ & Sangat Efektif \\
\hline
\end{tabular}

Sumber : Hasil Olahan, 2016

Berdasarkan Tabel 5. di atas dapat dilihat pada tahun 2012 penerimaan pajak sebesar Rp 2.199.387.592 telah mencapai target sebesar $\mathrm{Rp}$ 2.000.000.000 sehingga presentase keefektivitasannya mencapai $109.97 \%$. Dan pada tahun 2013 realisasi penerimaan pajak sebesar Rp 2.604.424.720 dari target sebesar Rp 2.000.000.000 sehingga presentase keefektivitasannya mencapai 130.22\%. Sedangkan pada tahun 2014 realisasi penerimaan pajak sebesar Rp 3.661.508.488 dari target sebesar Rp 2.300.000.000 sehingga presentase keefektivitasannya mencapai 159.20\%. Dapat disimpulkan bahwa, tingkat penerimaan pajak Mineral Bukan Logam di Kabupaten Minahasa tahun 2012 - 2014 semakin meningkat meskipun target pada tahun 2014 telah ditambahkan, sehingga penerimaan pajak tersebut tingkat interpretasi efektivitas tiap tahunnya terbilang sangat efektif terhadap Pendapatan Asli Daerah di Kabupaten Minahasa.

Sedangkan besarnya Kontribusi Pajak Mineral Bukan Logam Dan Batuan pada tahun 2012 sebesar 9.78\% dilihat dari hasil perbandingan pendapatan Pajak Mineral Bukan Logam Dan Batuan dengan pendapatan asli daerah. Pada tahun 2013 kontribusi pajak mineral bukan logam dan batuan menurun menjadi 8.14\% dan pada tahun 2014 terjadi penurunan kembali menjadi 6.22\%. Kontribusi tertinggi terdapat di tahun 2012 dan terendah terdapat di tahun 2014. Dari hasil ini, dapat disimpulkan bahwa kontribusi pajak mineral bukan logam dan batuan terhadap pendapatan asli daerah di Kabupaten Minahasa dari tahun 2012 sampai tahun 2014 sangat kurang.

Dari hasil tersebut dapat dilihat pada tabel interpretasi Kontribusi Pajak Mineral Bukan Logam Dan Batuan di Kabupaten Minahasa tahun 2012 - 2014 yang dapat dilihat pada Tabel 6. di bawah ini. 
Tabel 6. Kontribusi Pajak Mineral Bukan Logan dan Batuan

Kabupaten Minahasa

Tahun 2012 - 2014

\begin{tabular}{cccrc}
\hline Tahun & $\begin{array}{c}\text { Realisasi Pajak } \\
(\mathbf{R p})\end{array}$ & $\begin{array}{c}\text { Realisasi PAD } \\
(\mathbf{R p})\end{array}$ & Kontribusi & Interpretasi \\
\hline 2012 & 2.199 .387 .592 & 22.477 .366 .444 & $9.78 \%$ & Sangat Kurang \\
2013 & 2.604 .424 .720 & 31.964 .854 .060 & $8.14 \%$ & Sangat Kurang \\
2014 & 3.661 .508 .488 & $58.778 .368 .154,61$ & $6.22 \%$ & Sangat Kurang \\
\hline
\end{tabular}

Sumber : Hasil Olahan, 2016

\section{Pembahasan}

\section{Efektivitas}

Tingkat efektivitas Pajak Mineral Bukan Logam Dan Batuan di Kabupaten Minahasa dihitung dengan menggunakan rumus yang telah dipaparkan dengan cara sebagai berikut.

a.

$$
\text { 2.199.387.592 }
$$

$$
\begin{aligned}
\text { Tahun } 2012 & =\frac{2.199 .387 .592}{2.000 .000 .000} * 100 \% \\
& =109.97 \%
\end{aligned}
$$

b. $\quad 2.604 .424 .720$

$$
\begin{aligned}
\text { Tahun } 2013 & =\frac{2.604 .424 .720}{2.000 .000 .000} * 100 \% \\
& =130.22 \%
\end{aligned}
$$

c. 3.661 .508 .488

\section{Kontribusi}

$$
\begin{aligned}
\text { Tahun } 2014 & =\frac{3.661 .508 .488}{2.300 .000 .000} * 100 \% \\
& =159.20 \%
\end{aligned}
$$

Kontribusi Pajak Mineral Bukan Logam Dan Batuan terhadap PAD di Kabupaten Minahasa dihitung dengan rumus yang telah dipaparkan dengan cara sebagai berikut.

a. 2.199.387.592

$$
\begin{aligned}
\text { Tahun } 2012 & =\frac{22.477 .366 .444}{2} \times 100 \% \\
& =9.78 \%
\end{aligned}
$$

b.

$$
\begin{aligned}
\text { Tahun } 2013 & =\frac{2.604 .424 .720}{31.964 .854 .060} \times 100 \% \\
& =8.14 \%
\end{aligned}
$$

c.

$$
\begin{aligned}
\text { Tahun } 2014 & =\frac{3.661 .508 .488}{58.778 .368 .154,61} \times 100 \% \\
& =6.22 \%
\end{aligned}
$$


Faktor yang menyebabkan Kontribusi Pajak Mineral Bukan Logam dan Batuan dinyatakan sangat kurang karena target yang ditetapkan pemerintah pada Pendapatan Asli Daerah di Kabupaten Minahasa dari tahun 2012 sampai tahun 2014 terus ditingkatkan. Sehingga, meskipun penerimaan Pajak Mineral Bukan Logam Dan Batuan dari tahun 2012 sampai tahun 2014 terus mengalami peningkatan atau sangat efektif tidak akan memeberikan kontribusi besar pada Pendapatan Asli Daerah.

\section{Kesimpulan}

\section{PENUTUP}

Kesimpulan dalam penelitian ini adalah sebagai berikut.

1. Tingkat efektivitas di 3 (tiga) tahun tersebut terus mengalami peningkatan sehingga terbilang "sangat efektif". Tingkat efektivitas tahun 2012 mencapai 109.97\%, tahun 2013 tingkat efektivitas mencapai $130.22 \%$, sedangkan tahun 2014 tingkat efektivitas mencapai $159.20 \%$ meskipun target pada tahun ini telah ditambahkan dari tahun 2012 dan 2013 sebelumnya sebesar Rp 2.000.000.000 menjadi Rp 2.300.000.000.

2. Kontribusi pada tahun 2012 sebesar $9.78 \%$, tahun 2013 kontribusi sebesar $8.14 \%$ sedangkan pada tahun 2014 kontribusinya sebesar 6.22\%. Kontribusi terbesar terjadi pada tahun 2012 sedangkan terendah terjadi pada tahun 2014. Kontribusi Pajak Mineral Bukan Logam dan Batuan sebagai sumber Pendapatan Asli Daerah selama 3 (tiga) tahun terakhir dinilai tidak maksimal dan masuk dalam kriteria kontribusi "Sangat kurang".

3. Faktor yang menyebabkan Kontribusi Pajak Mineral Bukan Logam dan Batuan dinyatakan sangat kurang karena target yang ditetapkan pemerintah pada Pendapatan Asli Daerah di Kabupaten Minahasa dari tahun 2012 sampai tahun 2014 terus ditingkatkan. Sehingga, meskipun penerimaan Pajak Mineral Bukan Logam Dan Batuan dari tahun 2012 sampai tahun 2014 terus mengalami peningkatan atau sangat efektif tidak akan memeberikan kontribusi besar pada Pendapatan Asli Daerah.

Saran

Saran dalam penelitian ini adalah sebagai berikut.

1. Sistem pemungutan yang harus terus diawasi dan diperhatikan agar penerimaan Pajak Mineral Bukan Logam dan Batuan terkontrol dan tetap sangat efektif.

2. Lebih ditingkatkan lagi fungsi kontrol pemerintah terhadap instansi terkait demi terciptanya kinerja yang lebih baik sehingga tahun-tahun selanjutnya dapat memberikan hasil yang memuaskan. Dalam hal ini, Dinas Pendapatan Daerah dan Badan Pengelola Keuangan Dan Barang Milik Daerah tetap menjalin kerja sama yang baik dengan Dinas Energi dan Sumber Daya Mineral untuk melakukan pendataan ulang terhadap subjek pajak, wajib pajak, dan objek pajak serta masa Ijin Usaha Pertambangan (IUP) sehingga jelas waktu pemungutan Pajak Mineral Bukan Logam dan Batuan.

\section{DAFTAR PUSTAKA}

Adisasmita, Rahardjo. 2011.Pengelolaan Pendapatan dan Anggaran Daerah. Penerbit: Graha Ilmu, Jogyakarta.

Devy, Octaviana S. 2013, Analisis Efektivitas Dan Efisiensi Pajak Daerah Serta Kontribusinya

Terhadap Pendapatan Asli Daerah Di Provinsi Jawa Tengah. Fakultas Ekonomi Dan Bisnis

Universitas Dian Nuswantoro Semarang.

Hery. 2014. Akuntansi Perpajakan, Penerbit: PT Grasindo, Jakarta.

Indira, Pamela. 2014. Analisis Efektivitas Penerimaan Pajak dan Pengelolaan Mineral Bukan

Logam dan Batuan sebagai Sumber Pendapatan Asli Daerah Kota Tomohon. Fakultas Ekonomi

dan Bisnis, Universitas Sam Ratulangi Manado.

Lapian, Pingkan. 2015. Analisis Efektivitas Penerapan Pajak Sarang Burung Walet di Kabupaten

Minahasa. Fakultas Ekonomi dan Bisnis, Universitas Sam Ratulangi Manado.

Londorang,I. Marghareta. 2014. Penerapan Tax Planning Pajak Pertambahan Nilai Terhutang

Pada UD. Leonel. Fakultas Ekonomi dan Bisnis, Universitas Sam Ratulangi Manado. 
Mardiasmo. 2011. Perpajakan, Edisi Revisi, Penerbit : CV. Andi Offset, Yogyakarta.

Pemerintah RI. 2004. UU No. 34 tentangPemerintahan Daerah, Pajak Daerah dan Retribusi

Daerah.

Puspitasari, Diana Amelia. 2014, Analisis Efektivitas Dan Kontribusi Pajak Hotel Dan Restoran

Terhadap Penerimaan Asli Daerah Kota Bontang Tahun 2012-2014. Fakultas Ekonomi Universitas

Negeri Surabaya.

Rahmawati, Indah. 2014. Analisis Potensi Penerimaan Pajak Mineral Bukan Logam dan Batuan

Sebagai Sumber Pendapatan Asli Daerah Di Kabupaten Gresik. Fakultas Ekonomi dan Bisnis,

Universitas Brawijaya Malang.

Republik Indonesia. 2009. Undang-undang Nomor 28 tentang Pajak Daerah.

Resmi. 2011. Perpajakan, Penerbit : Salemba Empat, Jakarta.

Ricart, Hendrik. 2013. Analisis Efektivitas dan Kontribusi Penerimaan Pajak Bea Perolehan Hak

Atas Tanah dan Bangunan (BPHTB) Terhadap Penerimaan Pajak Daerah Kota Manado. Fakultas

Ekonomi dan Bisnis Universitas Sam Ratulangi Manado.

Ridha, Noor Widowati Dan Dhiah Fitrayati. 2013. Analisis Efektivitas Potensi Pemungutan Pajak

Mineral Bukan Logam Dan Batuan Di Kabupaten Bojonegoro. Prodi Pendidikan Ekonomi, Jurusan

Pendidikan Ekonomi, Fakultas Ekonomi Universitas Negeri Surabaya.

Rondonuwu, Ritno H.. 2015. Analisis Efektivitas Dan Efisiensi Pengelolaan Keuangan Daerah

Pada Dinas Pendapatan Daerah Kabupaten Minahasa Kabupaten Minahasa. Fakultas Ekonomi

dan Bisnis, Universitas Sam Ratulangi Manado.

Samudra, Azhari Aziz. 2015. Perpajakan di Indonesia : Keuangan, Pajak dan Retribusi Daerah. Penerbit : Rajawali Pers, Jakarta.

Suwardjono. 2014. Akuntansi Pengantar Bagian 1, Edisi Ketiga. Penerbit : BPFE, Yogyakarta.

Waluyo. 2013, Perpajakan Indonesia, Penerbit : Salemba Empat, Jakarta. 